\title{
Induction of cyclic ovarian activity in seasonally anoestrous ewes with exogenous GnRH
}

\author{
K. P. McNatty, Katherine Ball, Marion Gibb, Norma Hudson and \\ D. C. Thurley
}

Wallaceville Animal Research Centre, Private Bag, Upper Hutt, New Zealand

\begin{abstract}
Summary. Anoestrous ewes $(\mathrm{N}=3)$ were treated with a $500 \mathrm{ng}$ GnRH pulse administered via a jugular cannula every $2 \mathrm{~h}$ for 40 to 80 days. Plasma concentrations and therefore presumed ovarian activity changed cyclically with each progestational cycle $(n=10)$ lasting $14.0-18.5$ days. It is concluded that, by increasing the frequency of $\mathrm{GnRH}$ secretory episodes from an apparent endogenous level of one episode per $3.6 \mathrm{~h}$ to at least one every $2.0 \mathrm{~h}$, cyclic ovarian activity can be restored to seasonally anoestrous sheep.
\end{abstract}

\section{Introduction}

Preovulatory follicular development, oestrous activity, ovulation, and normal luteal function can be induced in progesterone-primed seasonally anoestrous ewes by a 72-h 'pulse-injection' regimen of luteinizing hormone $(\mathrm{LH})$ or gonadotrophin-releasing hormone $(\mathrm{GnRH})$, a 72 -h constant infusion regimen of LH or a sexually active ram (McNatty, Gibb, Dobson \& Thurley, 1981). However, when the corpus luteum has regressed after any of these treatments, the animals return once again to an anovulatory state for the remainder of the anoestrous period. Thus a short-term exposure of anoestrous ewes to $\mathrm{LH}, \mathrm{GnRH}$ or a ram does not lead to permanent restoration of cyclic ovarian activity during the non-breeding season.

During the breeding season, the pattern of LH secretion in Romney ewes during the luteal phase is characterized by discrete episodic discharges of the hormone occurring at a frequency of about one discharge every $2.2 \mathrm{~h}$. By contrast, during the non-breeding season, the episodic discharges of LH occur at a frequency of about one every $3.6 \mathrm{~h}$ (McNatty et al., 1981). It is possible that this difference is due to changes in the frequency of GnRH secretion from the hypothalamus (Carmel, Araki \& Ferin, 1976; Belchetz, Plant, Nakai, Keogh \& Knobil, 1978) rather than to any major change in the functional status of the pituitary gland per se (see Karsch, Goodman \& Legan, 1980, for review).

It ought therefore to be possible to induce and maintain cyclic ovarian activity in anoestrous Romney ewes by the administration of unvarying long-term GnRH pulses at a frequency comparable to that which presumably occurs during the luteal phase of the oestrous cycle. The present paper details the results of such a study.

\section{Materials and Methods}

\section{Experimental animals and treatment regimen}

Three parous New Zealand Romney ewes (aged $2 \frac{1}{2}$ years) were studied during anoestrus (2 ewes from September to December: 1 ewe from January to February). During the experimental period, the animals were housed indoors, in adjacent wooden crates, in which they were free to 
sit or stand. The animals were haltered to restrict sideways head movement and prevent access by the ewes to the cannulae inserted in their jugular veins. Mixtures of lucerne hay, lucerne pellets, sheep nuts, grass clippings and water were provided daily. Although indoors, the animals were facing windows and were exposed to natural lighting conditions similar to those outdoors.

Before the experiments began, the ovaries of each ewe were examined by laparoscopy to confirm that they were devoid of any obvious pathology and that no corpora lutea or signs of recent ovulations were visible at the ovarian surface. Following laparoscopy a Silastic tube (Medical grade: Dow Corning, Midland, Michigan, U.S.A.; i.d. $=0.030 \mathrm{~mm}$, o.d. $=0.065 \mathrm{~mm}$ ) was inserted into one jugular vein of each ewe. At the site of entry into the vein, the cannula was looped once through a plastic support which was stitched into the neck. The purpose of the support was to prevent any undue movement of the cannula into or out of the vein. This first cannula was used for introducing the GnRH into the animal. A second jugular cannula for blood sampling purposes (SV136; Medical grade: Dural Plastics and Engineering, New South Wales, Australia; i.d. $=2.0 \mathrm{~mm}$; o.d. $=3.0 \mathrm{~mm}$ ) was inserted into each animal and immobilized at the entry into the vein as described above.

Between 500 and 600 ng GnRH (Luliberin; Pierce Chemical Co., Rockford, Illinois, U.S.A.) were infused via the Silastic cannula into each animal over a 110-sec interval every 2 h for 74 (Ewe 1), 80 (Ewe 2) or 43 (Ewe 3) days. The cannula delivering the GnRH was coupled to an autoanalyser pump (Technicon Instruments, Tarrytown, New York, U.S.A.), which was activated automatically every $2 \mathrm{~h}$ by a timing device developed at the Wallaceville Research Centre. The GnRH solution for infusion was prepared each day and consisted of GnRH (500 $\mathrm{ng} / \mathrm{ml})$ and sodium heparin $(150 \mathrm{i} . \mathrm{u} . / \mathrm{ml})$ in sterile isotonic saline $(0.9 \mathrm{~g} \mathrm{NaCl} / \mathrm{l})$. A blood sample $(10 \mathrm{ml})$ was collected from each animal at least once every 3 days. After each blood sample had been withdrawn through the cannula, the latter was flushed with $2 \mathrm{ml}$ saline containing sodium heparin (150 i.u./ml). Thirty consecutive daily blood samples were obtained from 28 anoestrous Romney ewes between September and February for progesterone analysis. These animals, which served as a control group were housed and fed identically to the GnRH-treated animals, and also were not exposed to a ram. All blood samples were centrifuged $(4000 \mathrm{~g})$ within $30 \mathrm{~min}$ of collection at $18-20^{\circ} \mathrm{C}$ for $20 \mathrm{~min}$. The plasma was recovered and kept frozen at $-20^{\circ} \mathrm{C}$ until hormone analysis.

\section{Progesterone determinations}

Progesterone was measured in peripheral plasma by a radioimmunoassay procedure similar to that described by Thorneycroft \& Stone (1972) and validated as described by Neal, Baker, McNatty \& Scaramuzzi (1975). The antiserum (WA-26) was raised in an ovariectomized ewe against progesterone-11 $\alpha$-hemisuccinate conjugated to bovine serum albumin and used at an initial dilution of 1:5000. Major cross-reacting steroids in the assay were $11 \alpha$ hydroxyprogesterone (120\%), 11 -hydroxyprogesterone (25\%), 20a-dihydroprogesterone $(3.5 \%)$ and androstenedione $(0.45 \%)$. Under the assay conditions employed, the minimum detectable level of progesterone in plasma was $0.3 \mathrm{ng} / \mathrm{ml}$. The intra- and interassay coefficients of variation were $<14 \%$.

\section{Results}

The patterns of progesterone secretion in the ewes are shown in Text-fig. 1. In all 3 ewes, the levels of progesterone exceeded $1 \mathrm{ng} / \mathrm{ml}$ for 8-13 successive days on 2 or 4 separate occasions. For the ewes not subjected to GnRH treatment (i.e. the controls), the mean progesterone value was $0.41 \pm 0.01 \mathrm{ng} / \mathrm{ml}$ (s.e.m., $n=840)$ : only two $(0.23 \%)$ of the values (each from a different animal) were $\geqslant 1 \mathrm{ng} / \mathrm{ml}$. 


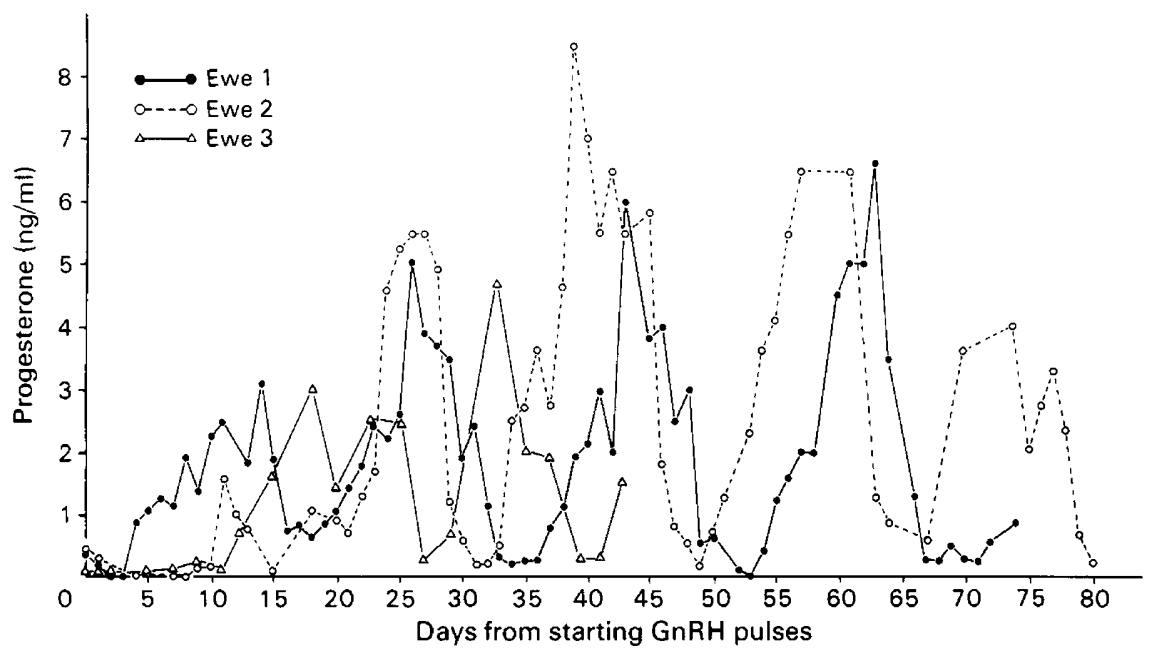

Text-fig. 1. Changes in the plasma concentrations of progesterone in Ewes 1,2 and 3 throughout the period when GnRH pulses were administered every $2 \mathrm{~h}$.

\section{Discussion}

These results show that a cyclic pattern of progesterone secretion can be induced and maintained in anoestrous ewes when GnRH is administered as a pulse once every $2 \mathrm{~h}$ on a continuous long-term basis. This cyclic pattern of progesterone secretion did not occur in the anoestrous control ewes in the absence of exogenous GnRH treatment or a sexually active ram (see also McNatty et al., 1981). It seems likely that the GnRH regimen induced cyclic ovarian activity via the increased secretions of LH and FSH. A single i.v. injection of $500 \mathrm{ng} \mathrm{GnRH}$ to anoestrous ewes results in peak levels of LH (amplitude $\sim 3 \mathrm{ng} / \mathrm{ml}$ ) in plasma $\sim 10 \mathrm{~min}$ later and a return to basal levels after 40-60 min (McNatty et al., 1981). The pattern of FSH secretion with the above dose of GnRH is not known.

The present finding that progesterone values exceeded $1 \mathrm{ng} / \mathrm{ml}$ for at least 8 successive days on 2-4 separate but consecutive occasions in each GnRH-treated animal, together with the fact that each progestational episode occurred over a 14.0- to 18.5-day interval (Text-fig. 1), suggests that at least one normal functional corpus luteum was formed on each occasion and that normal cyclic ovarian activity had been restored (Short, 1972).

The induction of cyclic progesterone secretion was delayed in Ewes 2 and 3 compared to that in Ewe 1, although in Ewe 2 there was some indication of activity on Days 11-13 (Text-fig. 1). It is possible that this comparatively abbreviated period of progesterone secretion in Ewe 2 was due to an inadequately developed corpus luteum (McNatty et al., 1981). In Ewe 1, ovulation was apparently induced within the first 2-4 days of $\mathrm{GnRH}$ treatment because the progesterone levels were already about $1 \mathrm{ng} / \mathrm{ml}$ on the 5 th day of the experiment: this finding adds further evidence to suggest that some follicles in anoestrous sheep can be recruited for their final stages of maturation and mobilized for oestrogen production within just a few hours of supplementing the endogenous production of LH and FSH (McNatty et al., 1981).

The results of this study support the concept that cyclic ovarian activity may be critically dependent on the frequency (and amplitude) of hypothalamic GnRH release as postulated for prepubertal and adult rhesus monkeys (Belchetz et al., 1978; Knobil, Plant, Wildt, Belchetz \& Marshall, 1980; Wildt, Marshall \& Knobil, 1980). 


\section{References}

Belchetz, P.E., Plant, T.M., Nakai, Y., Keogh, E.J. \& Knobil, E. (1978) Hypophysial responses to continuous and intermittent delivery of hypothalamic gonadotropin-releasing hormone. Science, N.Y. 202, 631-633.

Carmel, P.W., Araki, S. \& Ferin, M. (1976) Pituitary stalk portal blood collection in rhesus monkeys: evidence for pulsatile release of gonadotropinreleasing hormone (GnRH). Endocrinology 99, 243-248.

Karsch, F.J., Goodman, R.L. \& Legan, S.J. (1980) Feedback basis of seasonal breeding: test of an hypothesis. J. Reprod. Fert. 58, 521-535.

Knobil, E., Plant, T.M., Wildt, L., Belchetz, P.E. \& Marshall, G. (1980) Control of the rhesus monkey menstrual cycle: permissive role of hypothalamic gonadotropin-releasing hormone. Science, N.Y. 207, 1371-1373.

McNatty, K.P., Gibb, M., Dobson, C. \& Thurley, D.C. (1981) Evidence that changes in tonic luteinizing hormone secretion regulate the growth of the preovulatory follicle in the ewe. J. Endocr. 90, 375-389.

Neal, P., Baker, T.G., McNatty, K.P. \& Scaramuzzi, R.J. (1975) Influences of prostaglandins and human chorionic gonadotrophin on progesterone concentrations and oocyte maturation in mouse ovarian follicles maintained in organ culture. J. Endocr. 65, 19-25.

Short, R.V. (1972) Role of hormones in sex cycles. In Reproduction in Mammals, Book 3. Hormones in Reproduction, pp. 42-72. Eds C. R. Austin \& R. V. Short. Cambridge University Press.

Thorneycrof, I.H. \& Stone, S.C. (1972) Radioimmunoassay of serum progesterone in women receiving oral contraceptives. Contraception 5, 129-146.

Wildt, L., Marshall, G. \& Knobit, E. (1980) Experimental induction of puberty in the infantile female Rhesus Monkey. Science, N.Y. 202, 1373-1375.

Received 26 February 1981 